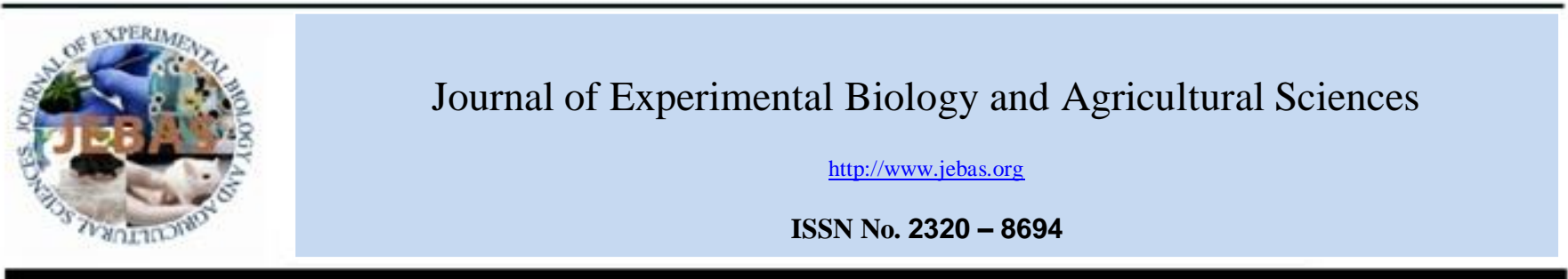

\title{
ANTAGONISTIC EFFECT OF Trichoderma ISOLATES ON Sclerotium rolfsii
}

\section{Subhas Chandra Jana ${ }^{1 *}$, Malay Mandal ${ }^{2}$}

${ }^{1}$ HOD, Department of Microbiology, Bidhannagar College, EB 2, Salt Lake, Kolkata 700064, West Bengal, India.

${ }^{2}$ Senior Research Fellow, P. G. Department of Microbiology, Bidhannagar College, EB 2, Salt Lake, Kolkata 700064, West Bengal, India

Received - February 26, 2017; Revision - May 09, 2017; Accepted - August 15, 2017

Available Online - September 10, 2017

DOI: http://dx.doi.org/10.18006/2017.5(4).506.514

\section{KEYWORDS}

S. rolfsii

Betelvine

Biocontrol

Trichoderma spp

\begin{abstract}
Present study was carried out with an aim to screen potential Trichoderma strains to control Sclerotium rolfsii. Among the eleven isolates, Seven $\left(\mathrm{T}_{1}, \mathrm{~T}_{3}, \mathrm{~T}_{4}, \mathrm{~T}_{5}, \mathrm{~T}_{7}, \mathrm{~T}_{9}\right.$ and $\left.\mathrm{T}_{11}\right)$ were preliminarily identified as T. harzianum while the rest four $\left(\mathrm{T}_{2}, \mathrm{~T}_{6}, \mathrm{~T}_{8}\right.$ and $\left.\mathrm{T}_{10}\right)$ were identified as $T$. viride. Further, results of study suggested that isolate $\mathrm{T}_{3}, \mathrm{~T}_{4}, \mathrm{~T}_{11}, \mathrm{~T}_{2}$ and $\mathrm{T}_{10}$ were effective against $\mathrm{S}$. rolfsii. Later, internal transcribed spacer (ITS)-1 sequence analysis confirmed isolate $\mathrm{T}_{3}$ as $T$. harzianum and $\mathrm{T}_{10}$ as $T$. viride. In dual culture plate technique, T. harzianum isolate $\mathrm{T}_{3}$ gave highest inhibition of $71.67 \%$, while $T$. viride isolate $\mathrm{T}_{10}$ stood second with an inhibition of $67.23 \%$. Trichoderma isolate $\mathrm{T}_{10}$ culture filtrate was found to be the most effective in non-volatile antimicrobial compound production. At $15 \%(\mathrm{v} / \mathrm{v})$ concentration level, it can totally suppress mycelium growth of $S$, rolfsii. Further, $T$. viride isolate $\mathrm{T}_{2}$ showed maximum potential in volatile antagonistic compound production with $53.26 \%$ radial growth inhibition, followed it with isolate $\mathrm{T}_{3}(52.17 \%$ of growth inhibition). All the five antagonistic isolates suppressed sclerotial germination and completely killed sclerotia within 20 days; only isolate $\mathrm{T}_{11}$ required 25 days. Isolate $\mathrm{T}_{10}$ was the most effective in germination suppression.
\end{abstract}

* Corresponding author

E-mail: subhas.c.jana.1959@gmail.com (Subhas Chandra Jana)

Peer review under responsibility of Journal of Experimental Biology and Agricultural Sciences.

Production and Hosting by Horizon Publisher India [HPI] (http://www.horizonpublisherindia.in/).

All rights reserved.
All the article published by Journal of Experimental Biology and Agricultural Sciences is licensed under a Creative Commons Attribution-NonCommercial 4.0 International License Based on a work at www.jebas.org.

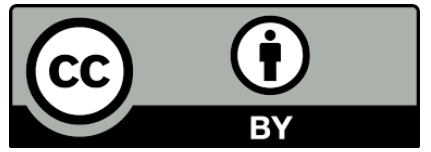




\section{Introduction}

Sclerotium rolfsii, a phytopathogenic fungus, often plays spoil sport in way of increasing betelvine production. It is a familiar soil borne polyphagous fungus, mainly dispersed in tropical and subtropical regions where soil temperature settles around $30^{\circ} \mathrm{C}$ (Harlapur, 1988). This fungus does not survive for a long period in most of the northern European countries as these regions are in fact excessively cold for this organism to survive. Practical, safe and fully satisfactory usable methods of $S$. rolfsii control have yet to be established. Use of chemical fungicides is limited due to high cost, wide host range and long persistence of sclerotia in soil (Pratt \& Rowe, 2002). However, difficulties in chemical mediated fungal control can also arise from regional climate change, position of land, atmospheric condition of field etc. Realizing environmental concern regarding over use of hazardous chemical fungicides to excel crop growth, greater emphasis is given on biological control to reduce environmental hazards, antifungal resistant strain development and cost of cultivation. Biological control of soil borne pathogens can offer environmentally safe, durable and cost effective alternative to chemicals (Erkol et al., 2011; Shafique et al., 2016). Biological control of plant diseases has been the subject of extensive research in last two decades. Trichoderma spp. have been reported and accomplished in controlling fungal phytopathogens in various cases (Kubicek, 2001; Harman et al., 2004; Celar \& Valic, 2005; Schwarze et al., 2012; Lee et al., 2012; Li et al., 2016). Although a lot of investigators have reported biocidal efficacy of Trichoderma spp. against number of soil borne plant pathogens, there is slight information obtainable on use of Trichoderma spp. as biocontrol agent against $S$. rolfsii, stem rot causing agent in betelvine. In view of the above research findings, present study was carried out with an aim to screen and isolate some potential Trichoderma strains for further use as biocontrol agents or biopesticides against S. rolfsii. This sort of study was worth exploring in order to improve product quality and reduce dependency on chemical fungicides.

\section{Materials and Methods}

\subsection{Materials}

\subsubsection{Samples}

For isolation of different strains of Trichoderma spp., rhizospehre soil samples of healthy betelvine plants were collected at different localities of Howrah (i.e. Belpukur, Bagnan etc.), West Bengal, India. S. rolfsii (NCIM Cat. No. 1084), the plant pathogen culture was collected from National Collection of Industrial Microorganisms (NCIM), Pune, India.

\subsubsection{Culture media}

Potato dextrose agar (PDA) was used for fungal culture for this Peeled potato $200 \mathrm{~g}$, Dextrose $20 \mathrm{~g}$, Distilled water $1000 \mathrm{~mL}$ was used and final $\mathrm{pH}$ was adjust to5.6 \pm 0.2 at $25{ }^{\circ} \mathrm{C}$. Trichoderma selective medium (TSM) media was prepared by using $\mathrm{MgSO}_{4}$, $7 \mathrm{H}_{2} \mathrm{O}: 0.2 \mathrm{~g}, \mathrm{~K}_{2} \mathrm{HPO}_{4}: 0.9 \mathrm{~g}, \mathrm{KCl}: 0.15 \mathrm{~g}, \mathrm{NH}_{4} \mathrm{NO}_{3}: 3.0 \mathrm{~g}$, Glucose: 3.0 g, Agar: 20 g, Rosebengal: 0.15 g, Chloramphenicol: $0.25 \mathrm{~g}$, Distilled water: $1000 \mathrm{~mL}$; final $\mathrm{pH}$ was adjust to $6.5 \pm 0.2$ at $25^{\circ} \mathrm{C}$.

\subsection{Methods}

\subsubsection{Isolation of Trichoderma spp. from soil}

Soil sample (10 g), was dissolved in $90 \mathrm{~mL}$ sterilized distilled water and inoculated onto Trichoderma selective medium (TSM) agar plates and incubated at $28 \pm 2{ }^{\circ} \mathrm{C}$ for 7 days. Plates were examined on daily basis and each appeared colony was taken as one colony forming unit (cfu). Individual colonies, isolated from same plates were transferred to freshly prepared potato dextrose agar plates. Pure cultures were maintained on potato dextrose agar slants in sterilized hard glass test tubes and stored at $4{ }^{\circ} \mathrm{C}$ for further use.

\subsubsection{Soil pH measurement}

Soil samples (10 g) containing Trichoderma spp. were dissolved in $20 \mathrm{~mL}$ distilled water to determine the $\mathrm{pH}$ range which is favorable for growth and development of this fungus. Soil $\mathrm{pH}$ was measured by pH meter (Elico, Model No. LI 614).

\subsubsection{Soil moisture content measurement}

Soil samples $(20 \mathrm{~g})$ were dried in hot air oven at $121{ }^{\circ} \mathrm{C}$ and calculated its weight loss after complete evaporation of water in order to determine moisture range which is favorable for growth and development of Trichoderma spp.

Soil moisture content by mass was calculated as per the formula:

Water $(\%)$ by mass $=($ wet mass - dry mass $) \times 100 /$ dry mass

\subsubsection{Identification of Trichoderma isolates}

Initially Trichoderma isolates were recognized on the basis of microscopic characters, conidiophore branching patterns and conidia morphology. For visual observation, isolates were grown on potato dextrose agar for 5 days. Growth rates, changes in medium colour and colony appearance were examined at regular basis. Final identification was done by using recommendations given by Rifai (1969), Bissetts (1984) and Samuel et al. (2002). Further, identification of the two most potent isolates were carried 
out by sequence analysis of internal transcribed spacer (ITS)-1 region of rDNA.

\subsubsection{Genomic DNA isolation, amplification of internal transcribed spacer (ITS)-1 region of DNA and sequencing}

Genomic DNA of Trichoderma isolate $\mathrm{T}_{3}$ and $\mathrm{T}_{10}$ were extracted by Hipur ${ }^{\mathrm{TM}}$ Fungal Genomic DNA Purification Kit (HiMedia, India). Purity of extracted DNA was determined by spectrophotometric method and only pure DNA (A260/280=1.8) was used for internal transcribed spacer (ITS)-1 region amplification using universal primers, ITS1 (5'-TCC GTA GGT GAA CCT GCG G-3') for forward and primer ITS4 (5'-TCC TCC GCT TAT TGA TAT GC-3') for reverse. PCR was performed within microcentrifuge tube in Mastercycler Personal with following protocols: initial denaturation for 5 minutes at 94 ${ }^{\circ} \mathrm{C}$, followed by 35 cycles consisting of denaturation at $94{ }^{\circ} \mathrm{C}$ for 1 minute, annealing at $55{ }^{\circ} \mathrm{C}$ for 1 minute, elongation at $72{ }^{\circ} \mathrm{C}$ for 2 minutes and then cycle was completed by a final elongation step for 5 minutes at $72{ }^{\circ} \mathrm{C}$. PCR products were analyzed by electrophoresis in $1.5 \%(\mathrm{w} / \mathrm{v})$ agarose gel with ethidium bromide $(0.5 \mu \mathrm{g} / \mathrm{mL})$. PCR products were gel extracted using QIA quick Gel Extraction Kit (Qiagen, Germany). Sequencing were performed in an 8 capillary genetic analyzer (Applied Biosystems, USA) with Big Dye Terminator v3.1 Cycle Sequencing Kit (Applied Biosystems, USA) following manufacturer's instruction using the above forward and reverse primers. Obtained nucleotide sequences were assembled using sequence alignment editor program Bioedit (http://www.mbio.ncsu.edu/BioEdit/bioedit.html) and was compared in GenBank after BLAST searches (Altschul et al., 1997) using EzTaxon-e server (Chun et al., 2007). ITS-1 region (of rDNA) sequences of type strains obtained from EzTaxon-e server, showing more than $97 \%$ pair wise sequence similarity, were considered for phylogenetic analysis. A neighbor joining phylogenetic tree was constructed according to Kimura two-parameter model using the MEGA 5 (Tamura et al., 2011) software package (The Biodesign Institute, Arizona, USA). Robustness of tree was conducted by bootstrapping analysis based on 1,000 replicates.

\subsubsection{Antagonism studies}

To investigate whether antagonism existed between test fungi and pathogen ( $S$. rolfsii), $0.5 \mathrm{~cm}$ disc of antagonistic fungi and test microorganism (taken from actively growing 3-day-old culture) were placed at centre of potato dextrose agar plates, at $2 \mathrm{~cm}$ apart. Three replicates were prepared for each Trichoderma isolates. Respective controls were taken as well. Plates were incubated at $30 \pm 1{ }^{\circ} \mathrm{C}$ for 7 days. Growth pattern and antagonistic colony interaction were studied day by day. Antagonism nature and degree were determined according to the classification of
Skidmore and Dickinsons (Skidmore \& Dickinson, 1976) as follows:

\begin{tabular}{|lc|} 
Colony interaction & $\begin{array}{c}\text { Antagonism } \\
\text { types }\end{array}$ \\
\hline Mutual intermingling growth & $\mathrm{A}$ \\
\hline Overgrowth by antagonists & $\mathrm{Bi}$ \\
\hline $\begin{array}{l}\text { Intermingling growth in which the test fungus under } \\
\text { observation has ceased growth and is overgrown by } \\
\text { another colony }\end{array}$ & $\mathrm{Bii}$ \\
\hline Light inhibition & $\mathrm{C}$ \\
\hline Not detected & $\mathrm{D}$ \\
\hline
\end{tabular}

\subsubsection{Evaluation of antagonistic potential of Trichoderma isolates}

Test was conducted to evaluate antagonistic effect of Trichoderma isolates against $S$. rolfsii on potato dextrose agar medium by dual culture plate technique (Kucuck \& Kivanc, 2003). One mycelia disc $(0.5 \mathrm{~cm})$ of individual isolate and one mycelia disc $(0.5 \mathrm{~cm})$ of the test pathogen (both taken from actively growing 3-day-old culture) were placed simultaneously $1 \mathrm{~cm}$ from the edge of each petriplate at opposite direction. Three replicates were used for each set of experiment. Potato dextrose agar plates with only mycelia disc of $S$. rolfsii was served as control. Plates were incubated at $30 \pm 1{ }^{\circ} \mathrm{C}$. Percentage inhibition of $S$. rolfsii was calculated as per the formula cited by Sundar et al. (1995)

Inhibition of growth $(\%)=[(\mathrm{A}-\mathrm{B}) \mathrm{X} 100] / \mathrm{A}$

$\mathrm{A}=$ Mycelia growth of the pathogen without Trichoderma spp. (control).

B = Mycelia growth of the pathogen in presence of Trichoderma spp.

2.2.7. Effect of non-volatile compounds produced by antagonist(s) on radial growth of $S$. rolfsii

Production of non-volatile substances by selected Trichoderma isolates against test pathogen was studied as per method described by Dennis \& Webster (1971). Each Trichoderma isolate was inoculated in $100 \mathrm{~mL}$ sterilized potato dextrose broth in $250 \mathrm{~mL}$ conical flasks and incubated at $30 \pm 1{ }^{\circ} \mathrm{C}$ on a rotary shaker with intermittent shaking at $150 \mathrm{rpm}$ for 15 days. Later culture was filtered through Whatmann No.1 filter paper and centrifuged at $10000 \mathrm{rpm}$ for 10 minutes for removing mycelial mats. After sterilization by passing through $0.4 \mu \mathrm{m}$ biological membrane filter, filtrate was added to melted potato dextrose agar medium (at $40 \pm 2{ }^{\circ} \mathrm{C}$ ) to make concentration of $5 \%, 10 \%$ 
and $15 \%(\mathrm{v} / \mathrm{v})$ in petriplate. Filtrate amended potato dextrose agar containing plates were inoculated with $0.5 \mathrm{~cm}$ mycelial disc of $S$. rolfsii at the centre of petriplate and incubated at $30 \pm 1{ }^{\circ} \mathrm{C}$ for 5 days or until colony reached edge of petriplate. There were three replicates for each treatment. Two types of control, plate without any kind of culture and only pathogen culture without filtrate, was taken. Radial growth of pathogen was taken daily and percent inhibition was calculated by using following formula.

Inhibition of growth $(\%)=[(\mathrm{C}-\mathrm{T}) \times 100] / \mathrm{C}$

$\mathrm{C}=$ Mycelia growth of the pathogen (S. rolfsii) without filtrate (control).

$\mathrm{T}=$ Mycelia growth of the pathogen in presence of filtrate

2.2.8. Effect of volatile compounds produced by antagonist(s) on radial growth of $S$. rolfsii

Selected isolates were tested for production of inhibitory volatile metabolites to seize growth of $S$. rolfsii. "Inverted plate technique" by Dennis \& Webster (1971) was used for this study. Agar discs $(0.5 \mathrm{~cm}$ in diameter) were cut from actively growing (3-day-old) Trichoderma isolates and placed on centre of a potato dextrose agar plate. Similarly, $0.5 \mathrm{~cm}$ mycelial disc of $S$. rolfsii was inoculated at the centre of separate potato dextrose agar plates of same diameter. Subsequently, upper lids of both plates were removed and plate containing S. rolfsii was inverted over the plate containing Trichoderma isolate. Then, both plates were sealed at junction with parafilm. Control plate was maintained with Sclerotium plate inverted and sealed over an uninoculated potato dextrose agar plate. Each treatment was replicated thrice. All plates were incubated at $30 \pm 1{ }^{\circ} \mathrm{C}$ for 7 days. Observations on radial growth of pathogen were taken regularly and percent inhibition was calculated by comparing with control plate as described earlier.

2.2.9. Activity of Trichoderma isolates on sclerotia germination in liquid medium

Sclerotia of similar size and shape from a 15-day-old culture plate were inoculated in $250 \mathrm{~mL}$ potato dextrose broth (in Erlenmeyer flasks), containing culture filtrate of different strains of Trichoderma isolates. Three flasks for each Trichoderma filtrate were maintained. Sclerotia, inoculated in sterilized saline water were served as control. Sclerotia were removed from each flask at regular interval and plated onto fresh potato dextrose agar plates after surface sterilization with $0.2 \% \mathrm{HgCl}_{2}$. The process was repeated till no sclerotia remained viable in treatment flasks.

\section{Results}

\subsection{Isolation of Trichoderma spp.}

Eleven Trichoderma spp. was isolated from twenty four soil samples collected from different betelvine agricultural fields in Bagnan, Howrah. Most of these isolated colonies were plumose with white floccose surface along with scattered green patches. Pigment was secreted and diffused into medium during growth of isolates.

\subsection{Soil $\mathrm{pH}$ and moisture measurement}

Trichoderma spp. showed its ability to grow and develop in different $\mathrm{pH}$ ranging from 4.45 to 7.97 , with mean soil $\mathrm{pH}$ value of 6.21 (Table 1). This demonstrated that Trichoderma spp. is distributed widely in various soil conditions with different $\mathrm{pH}$ values. It can grow and sustain also in various humid conditions ranging from 18.85$47.34 \%$ with average moisture content of $32.34 \%$.

Table $1 \mathrm{pH}$ values of soils containing Trichoderma spp.

\begin{tabular}{ccc|} 
Isolate No. & $\mathrm{pH}$ value & Moisture content (\%) \\
\hline 1 & 4.45 & 18.85 \\
\hline 2 & 5.18 & 20.75 \\
\hline 4 & 4.67 & 20.75 \\
\hline 5 & 7.97 & 47.34 \\
\hline 6 & 6.7 & 31.23 \\
\hline 7 & 6.53 & 34.56 \\
\hline 8 & 5.98 & 27.91 \\
\hline 9 & 7.87 & 43.35 \\
\hline 10 & 6.42 & 43.45 \\
\hline 11 & 5.93 & 34.12 \\
\hline Mean & 6.61 & 33.47 \\
\hline
\end{tabular}

\subsection{Identification of isolates}

Among eleven isolates, seven isolates (Isolate $\mathrm{T}_{1}, \mathrm{~T}_{3}, \mathrm{~T}_{4}, \mathrm{~T}_{5}, \mathrm{~T}_{7}, \mathrm{~T}_{9}$ and $\mathrm{T}_{11}$ ) were preliminary identified as $T$. harzianum and rest of the isolates (Isolate $\mathrm{T}_{2}, \mathrm{~T}_{6}, \mathrm{~T}_{8}$ and $\mathrm{T}_{10}$ ) were T. viride (Table 2). Further, sequence analysis result of internal transcribed spacer (ITS)-1 region of DNA confirmed isolate $\mathrm{T}_{3}$ to be $T$. harzianum and isolate $\mathrm{T}_{10}$ as $T$. viride (Figure 1). 
Table 2 Characterization and identification of Trichoderma isolates

$\mathrm{T}_{1}, \mathrm{~T}_{3}, \mathrm{~T}_{4}, \mathrm{~T}_{5}, \mathrm{~T}_{7}$, At early stage, whitish to greenish mycelia appeared. Gradually deep green colour

Trichoderma harzianum

$\mathrm{T}_{9}, \mathrm{~T}_{11}$ developed in central part and extended to periphery of plate. Finally, it appeared a dull green colour. Mostly spherical, smooth conidia produced on condiophore.

$\mathrm{T}_{2}, \mathrm{~T}_{6}, \mathrm{~T}_{8}, \mathrm{~T}_{10} \quad$ Colony was observed to be whitish at early stage (3-4 days). Gradually from light green, dark green coloured mycelia mat exhibited at the central part of PDA plate. Condiophores were erect, compact, woolly pencillately branched. Conidia was hyaline, subglobuse, curve shaped, oval and smooth walled.

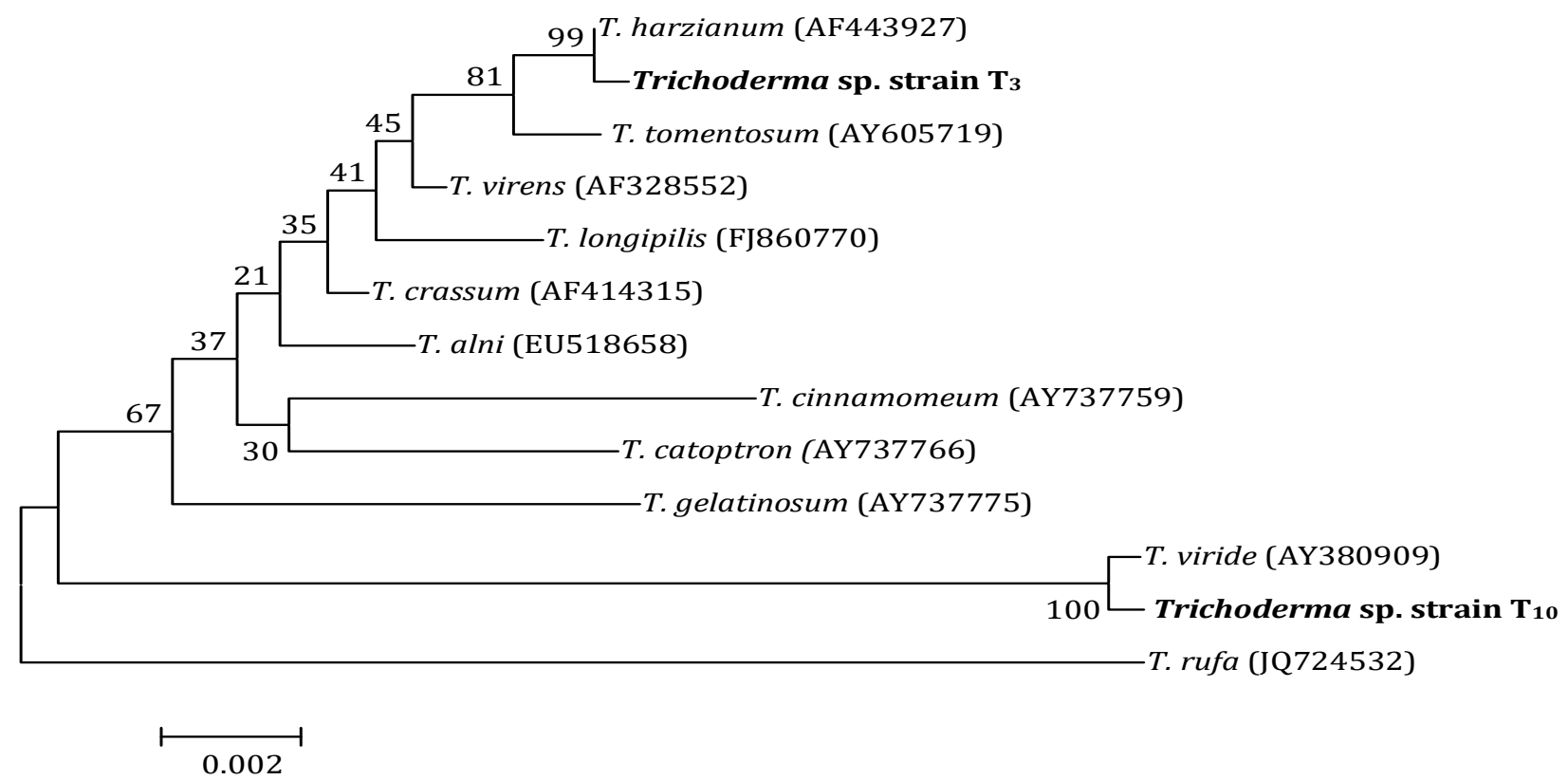

FFigure 1 Phylogenetic tree for Trichoderma isolates $\mathrm{T}_{3}$ and $\mathrm{T}_{10}$ using neighbour-joining method (Among closely related type species showing more than $97 \%$ sequence similarity. Bootstrap values (based on 1000 replicates) $>50 \%$ are given at branch points. Accession numbers are given in parentheses. Bar: 2 substitutions per 1000 nucleotide position).

\subsection{Antagonism study}

Eleven isolates were tested to find out their antagonistic potential and nature of colony interaction against test pathogen, S. rolfsii. Three $T$. harzianum isolates $\left(\mathrm{T}_{3}, \mathrm{~T}_{4}\right.$ and $\left.\mathrm{T}_{11}\right)$ showed $\mathrm{Bi}$ type of interaction (Table 3), antagonist inhibited growth of $S$. rolfsii by overgrowing. Whereas, $T$. viride isolate $\mathrm{T}_{2}$ and $\mathrm{T}_{10}$ showed Bii type of interaction. From laboratory study, it was observed that among the test fungi, T. harzianum isolate $\mathrm{T}_{3}, \mathrm{~T}_{4}$ and $\mathrm{T}_{11}$ and $T$. viride isolate $\mathrm{T}_{2}$ and $\mathrm{T}_{10}$ were mainly effective against $S$. rolfsii.
Table 3 Types of colony interaction of the antagonists with test fungus ( $S$. rolfsii)

\begin{tabular}{|ccc|}
\hline $\begin{array}{c}\text { Isolate } \\
\text { No. }\end{array}$ & Name of the antagonist & $\begin{array}{c}\text { Type of } \\
\text { interaction }\end{array}$ \\
\hline $\mathrm{T}_{1}$ & $T$. harzianum & $\mathrm{C}$ \\
\hline $\mathrm{T}_{2}$ & $T$. viride & $\mathrm{Bii}$ \\
\hline $\mathrm{T}_{3}$ & $T$. harzianum & $\mathrm{Bi}$ \\
\hline $\mathrm{T}_{4}$ & $T$. harzianum & $\mathrm{Bi}$ \\
\hline $\mathrm{T}_{5}$ & $T$. harzianum & $\mathrm{C}$ \\
\hline $\mathrm{T}_{6}$ & $T$. viride & $\mathrm{C}$ \\
\hline $\mathrm{T}_{7}$ & $T$. harzianum & $\mathrm{C}$ \\
\hline $\mathrm{T}_{8}$ & $T$. viride & $\mathrm{C}$ \\
\hline $\mathrm{T}_{9}$ & $T$. harzianum & $\mathrm{C}$ \\
\hline $\mathrm{T}_{10}$ & $T$. viride & $\mathrm{Bii}$ \\
\hline $\mathrm{T}_{11}$ & $T$. harzianum & $\mathrm{Bi}$ \\
\hline
\end{tabular}


In dual culture plate technique, pairing of Trichoderma isolates with $S$. rolfsii gave rise to growth reduction of test plant pathogen. T. harzianum isolate $\mathrm{T}_{3}$ produced highest inhibition of $71.67 \%$, while $T$. viride isolate $\mathrm{T}_{10}$ showed an inhibition of $67.23 \%$. Reduction in radial growth of $S$. rolfsii by $T$. harzianum and $T$. viride differed significantly $(\mathrm{P}>0.05)$ from that of the growth of $S$. rolfsii without antagonist as shown in Figure 2.

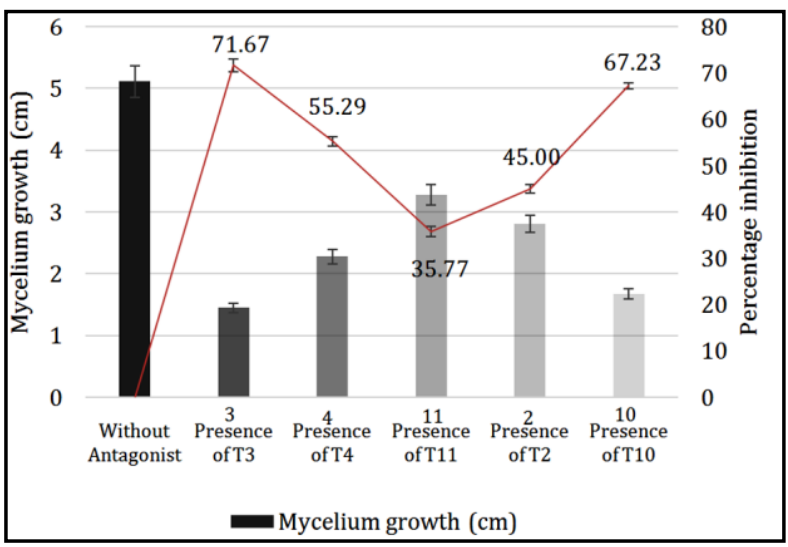

Figure 2 Percentage growth inhibition of S. rolfsii paired with Trichoderma isolates
3.5 Effect of non-volatile compounds produced by antagonist(s) on radial growth of $S$. rolfsii

Among Trichoderma isolates, irrespective of concentration and time of incubation, Trichoderma isolate $\mathrm{T}_{10}$ culture filtrate was found to be the most effective. At 15\% concentration level, it can totally suppress mycelia growth. Trichoderma isolate $\mathrm{T}_{3}$ recorded radial growth of $1.7 \mathrm{~cm}$ on $8^{\text {th }}$ day of incubation in comparison to control, representing $81.52 \%$ mycelia growth rate inhibition at $15 \%(\mathrm{v} / \mathrm{v})$ concentration level. In case of isolate $\mathrm{T}_{11}, S$. rolfsii showed highest radial growth $(7.12 \mathrm{~cm})$ on $8^{\text {th }}$ day of incubation, indicating the least inhibition (Table 4).

\subsection{Effect of volatile compounds produced by antagonist(s) on radial growth of $S$. rolfsii}

Among five different Trichoderma isolates, T. viride isolate $\mathrm{T}_{2}$ showed maximum potential in volatile antagonistic compound production with $53.26 \%$ radial growth inhibition on $8^{\text {th }}$ day of incubation (Table 5). Isolate $\mathrm{T}_{3}$ followed it with $52.17 \%$ of growth inhibition. Except isolate $\mathrm{T}_{10}$, other four Trichoderma isolates $\left(\mathrm{T}_{3}, \mathrm{~T}_{4}, \mathrm{~T}_{11}\right.$ and $\left.\mathrm{T}_{2}\right)$ had potential to produce volatile compound to inhibit $S$. rolfsii.

Table 4 Effect of non-volatile compounds produced by antagonist(s) on radial growth of $S$. rolfsii

\begin{tabular}{|c|c|c|c|c|c|c|}
\hline \multirow{2}{*}{$\begin{array}{c}\text { Incubation } \\
\text { period }\end{array}$} & \multicolumn{6}{|c|}{ Trichoderma filtrate concentration (\%) in medium (v/v) } \\
\hline & $5 \%$ & Inhibition (\%) & $10 \%$ & Inhibition (\%) & $15 \%$ & Inhibition (\%) \\
\hline \multicolumn{7}{|c|}{ Isolate $\mathrm{T}_{3}$} \\
\hline 4 days & $4.34 \pm 0.01$ & $15.73 \pm 0.04$ & $3.10 \pm 0.04$ & $39.81 \pm 0.03$ & $1.20 \pm 0.03$ & $76.70 \pm 0.02$ \\
\hline 8 days & $8.3 \pm 0.01$ & $9.78 \pm 0.02$ & $6.40 \pm 0.03$ & $30.43 \pm 0.01$ & $1.70 \pm 0.01$ & $81.52 \pm 0.04$ \\
\hline \multicolumn{7}{|c|}{ Isolate $\mathrm{T}_{4}$} \\
\hline 4 days & $4.7 \pm 0.03$ & $8.74 \pm 0.01$ & $3.90 \pm 0.02$ & $24.27 \pm 0.01$ & $3.10 \pm 0.03$ & $39.81 \pm 0.02$ \\
\hline 8 days & $8.6 \pm 0.01$ & $6.52 \pm 0.03$ & $6.70 \pm 0.03$ & $27.17 \pm 0.02$ & $5.20 \pm 0.02$ & $43.48 \pm 0.01$ \\
\hline \multicolumn{7}{|c|}{ Isolate $\mathrm{T}_{11}$} \\
\hline 4 days & $4.9 \pm 0.03$ & $4.85 \pm 0.01$ & $4.20 \pm 0.01$ & $18.45 \pm 0.01$ & $3.87 \pm 0.01$ & $24.85 \pm 0.03$ \\
\hline 8 days & $8.6 \pm 0.03$ & $6.52 \pm 0.02$ & $7.30 \pm 0.02$ & $20.65 \pm 0.03$ & $7.12 \pm 0.03$ & $22.61 \pm 0.04$ \\
\hline \multicolumn{7}{|c|}{ Isolate $\mathrm{T}_{2}$} \\
\hline 4 days & $4.8 \pm 0.04$ & $6.80 \pm 0.03$ & $4.00 \pm 0.03$ & $22.33 \pm 0.02$ & $3.40 \pm 0.03$ & $33.98 \pm 0.01$ \\
\hline 8 days & $8.5 \pm 0.03$ & $7.61 \pm 0.01$ & $6.90 \pm 0.04$ & $25.00 \pm 0.01$ & $5.90 \pm 0.02$ & $35.87 \pm 0.03$ \\
\hline \multicolumn{7}{|c|}{ Isolate $\mathrm{T}_{10}$} \\
\hline 4 days & $2.9 \pm 0.03$ & $43.69 \pm 0.01$ & $1.05 \pm 0.03$ & $79.61 \pm 0.01$ & 0 & 100.00 \\
\hline 8 days & $4.54 \pm 0.01$ & $50.65 \pm 0.02$ & $1.55 \pm 0.02$ & $83.15 \pm 0.04$ & 0 & 100.00 \\
\hline
\end{tabular}

*Each value is an average of 3 replicate samples \pm standard deviation in $\mathrm{cm}$; Control growth @ Day 4: 5.15 $\pm 0.02 \mathrm{~cm}$ and Day 8: $9.20 \pm 0.01 \mathrm{~cm}$ 
Table 5 Effect of volatile compounds produced by antagonist(s) on the radial growth of $S$. rolfsii

\begin{tabular}{|c|c|c|}
\hline \multirow[b]{2}{*}{ Time } & \multicolumn{2}{|c|}{ Effect of volatile compounds } \\
\hline & $\begin{array}{l}\text { Mycelia growth } \\
\text { (cm) }\end{array}$ & Inhibition (\%) \\
\hline \multicolumn{3}{|c|}{ Isolate $\mathrm{T}_{3}$} \\
\hline 4 days & $3.15 \pm 0.02$ & $43.69 \pm 0.04$ \\
\hline 8 days & $4.95 \pm 0.03$ & $52.17 \pm 0.05$ \\
\hline \multicolumn{3}{|c|}{ Isolate $\mathrm{T}_{4}$} \\
\hline 4 days & $3.00 \pm 0.01$ & $41.75 \pm 0.03$ \\
\hline 8 days & $4.70 \pm 0.02$ & $48.91 \pm 0.02$ \\
\hline \multicolumn{3}{|c|}{ Isolate $\mathrm{T}_{11}$} \\
\hline 4 days & $2.90 \pm 0.01$ & $38.83 \pm 0.02$ \\
\hline 8 days & $4.40 \pm 0.02$ & $46.20 \pm 0.01$ \\
\hline \multicolumn{3}{|c|}{ Isolate $\mathrm{T}_{2}$} \\
\hline 4 days & $2.80 \pm 0.02$ & $45.63 \pm 0.024$ \\
\hline 8 days & $4.30 \pm 0.01$ & $53.26 \pm 0.05$ \\
\hline \multicolumn{3}{|c|}{ Isolate $\mathrm{T}_{10}$} \\
\hline 4 days & $5.10 \pm 0.02$ & $0.97 \pm 0.04$ \\
\hline 8 days & $9.10 \pm 0.03$ & $1.09 \pm 0.03$ \\
\hline
\end{tabular}

*Each value is an average of 3 replicate samples \pm standard deviation, Control Growth @ Day 4: 5.15 \pm 0.02 and Day 8: $9.20 \pm 0.01$

\subsection{Activity of Trichoderma isolates on sclerotia germination in liquid medium}

Results of viability test are given in Figure 3, which shows that isolate $T_{10}$ was the most effective and isolate $T_{11}$ was the least effective antagonist among tested Trichoderma isolates. All the five antagonistic isolates suppressed sclerotial germination and completely killed sclerotia within 20 days; only isolate $\mathrm{T}_{11}$ required 25 days. After 25 days, no sclerotia were found viable in treatment assay flasks; however $100 \%$ sclerotia remained viable in control flasks.

\section{Discussion}

In this study, two Trichoderma species viz. T. harzianum (seven strains) and $T$. viride (four strains) were isolated from soil samples. Finding of this study suggested that Trichoderma is very common in soil and root ecosystem, hence can be easily isolated from soil and other organic material. Ubiquitous saprobe nature of Trichoderma have also been reported earlier by Harman et al. (2004) and Zeilinger \& Omann (2007).

In dual culture plate experiment, isolated Trichoderma strains were concurrently paired with $S$. rolfsii on potato dextrose agar plate for 7 days to observe pattern of antagonism and compare ability of isolated Trichoderma strains to compete with pathogen fungi for space and nutrients. From results, it was clear that $T$. harzianum isolate $\mathrm{T}_{3}$ had the highest potential to inhibit $S$. rolfsii

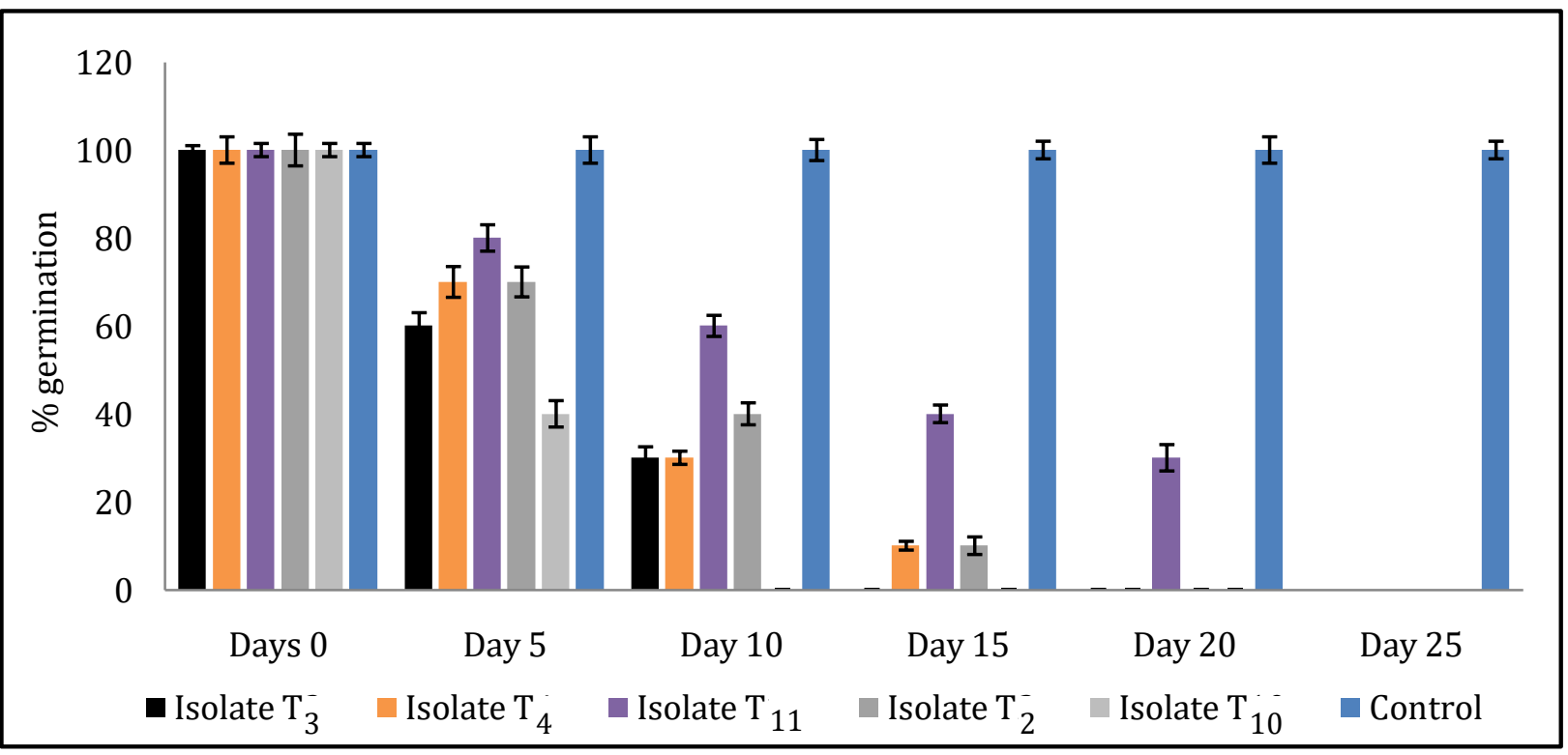

Fig. 3 Activity of Trichoderma spp. on sclerotia germination in liquid medium 
(71.67\% inhibition) followed by $T$. viride isolate $\mathrm{T}_{10}(67.23 \%$ inhibition). Results indicated that isolate $\mathrm{T}_{3}$ and $\mathrm{T}_{10}$ can parasitize $S$. rolfsii hyphae by means of penetration and growth inside hyphae of $S$. rolfsii. These findings showed parity with the observations made by Nagamma \& Nagaraja (2015). Earlier, Howell (2003) also suggested substantial antagonistic effect of $T$. harzianum on mycelia growth of S. rolfsii. As reported in present study, inhibition of $S$. rolfsii in dual culture plate experiment can be attributed to more rapidly growing ability of Trichoderma species and secretion of toxic extra cellular compounds such as antibiotics and cell wall degrading enzymes, i.e. $\beta$-1,3-glucanases, chitinases and proteases (Howell, 2003; Gajera et al., 2012). During mycoparasitic activity, these enzymes lyse hyphal cell wall of pathogens. According to study by Samieto et al., (2010), antagonism by both T. harzinium and T.viride strains is achieved through a multi-factorial process that required synergistic contribution of several mechanisms including entwining hyphae, spores attachment to its host, growing inside host conidia and subsequently death of host conidia.

Mycelia growth inhibition of $S$. rolfsii by isolated Trichoderma culture filtrate in liquid medium varied from $22.61 \%$ to $100 \%$. This kind of result is analogous to study by Sivasithamparam \& Ghisalberti (1998), which indicated that different species of same family and different strains of same species often can inhibit pathogens in significantly diverse manner as secondary metabolites express individuality of species in chemical terms. Mycelial growth inhibition by non-volatile compounds could be due to vacuolation, granulation, coagulation and lastly disintegration of cell wall by metabolites produced by Trichoderma isolates.

T. viride isolate $\mathrm{T}_{2}$ inhibited growth of $S$. rolfsii mostly followed by Isolate $\mathrm{T}_{3}$ by means of volatile compound production. In this context, Shaigan et al. (2008) stated the effect of volatile metabolites produced by $T$. viride, $T$. harzianum and $T$. longibrachiatum on $S$. rolfsii with mycelia growth inhibition of $60.8,58.8$ and $58.4 \%$ respectively, just as occurred in this bioassay. Volatile compounds were different among isolated strains of Trichoderma and mycelia growth inhibition by volatile compounds was prominently heterogeneous, even in strains of same species. Variable production of volatile metabolites by Trichoderma strains was reported by Amin et al. (2010). They even mentioned production of different metabolites by particular strain in different stages of development in dissimilar growth conditions.

From viability test, it was evident that all Trichoderma isolates could suppress sclerotia germination to a large extent. Isolate $\mathrm{T}_{10}$ had the most, while $T_{11}$ had the least potential as sclerotia germination suppressing bio agent. Within a span of 25 days from treatment, viable sclerotia had no traces in flask.

\section{Conclusion}

Two of the five selected Trichoderma isolates could effectively inhibit growth of $S$. rolfsii under laboratory conditions. S. rolfsii inhibiting ability of Trichoderma isolates can be explained taking into account of their capability to compete and exhibit mycoparasitism. These results suggested possible promising application of these isolated Trichoderma spp. against different phytopathogenic fungi.

\section{Acknowledgement}

This research was supported by grants from Department of Science and Technology, West Bengal (DST-WB).

\section{Conflict statement:}

The authors certify that they have no conflict of interests.

\section{References}

Altschul SF, Madden TL, Schaffer AA, Zhang J, Zhang Z, Miller W (1997) Gapped BLAST and PSIBLAST: a new generation of protein database search programs. Nucleic Acids Research 25: 3389-3402.

Amin F, Razdan VK, Mohiddin FA, Bhat KA, Sheikh PA (2010) effect of volatile metabolites of trichoderma species against seven fungal plant pathogens in-vitro Journal of Phytology 2: 34-37.

Bissett J (1984) A revision of the genus Trichoderma. I. section Longibrachiatum. sect. nov. Canadian Journal of Botany 62: 924931. DOI: $10.1139 / \mathrm{b} 84-131$.

Celar F, Valic N (2005) Effects of Trichoderma spp. and Glicladium roseum culture filtrates on seed germination of vegetables and maize. Journal of Plant Diseases and Protection, 112: 343-350.

Chun J, Lee JH, Jung Y, Kim M, Kim S, Kim BK, Lim YW (2007) EzTaxon: A web based tool for the identification of prokaryotes based on 16S ribosomal RNA gene sequences. International Journal of Systemic and Evolutionary Microbiology 57: 2259-2261. doi: 10.1099/ijs.0.64915-0

Dennis C, Webster J (1971a) Antagonistic properties of species groups of Trichoderma III, Hyphal interactions. Transactions of the British Mycological Society 57: 363-369.

Erkol D, Elif D, Cafer E (2011) In vitro antagonistic activity of fungi isolated from sclerotia on potato bubbers against Rhizoctonia solani. Turkish Journal of Biology 35: 457-462. doi:10.3906/biy-1004-98. 
Gajera HP, Bambharolia RP, Patel SV, Khatrani TJ, Goalkiya BA (2012) Antagonism of Trichoderma spp. against Macrophomina phaseolina: Evaluation of Coiling and Cell Wall Degrading Enzymatic Activities. Journal of Plant Pathology and Microbiology 3:149. doi:10.4172/2157-7471.1000149.

Harlapur SI (1988) Studies on some aspects of foot rot to wheat caused by Sclerotium rolfsii Sacc. M.Sc. (Agri) Thesis, University of Agricultural Sciences, Dharwad, Pp. 98-99.

Howell CR (2003) Mechanisms Employed by Trichoderma Species in the Biological Control of Plant Diseases: The History and Evolution of Current Concepts. Plant Disease 87: 4-10

Harman GE, Howell CR, Viterbo A, Vhet I, Lorito M (2004) Trichoderma species: opportunistic, avirulent plant symbiots. Nature Reviews Microbiology 2: 43-56. doi:10.1038/nrmicro797.

Kubicek CP (2001) Trichoderma: from genes to biocontrol. Journal of Plant Pathology 83: 11-23.

Kucuk C, Kivanc M (2003) Isolation of Trichoderma Spp. and determination of their antifungal, biochemical and physiological features Turkish Journal of Biology 27: 247-253.

Lee J, Huh N, Hong HJ, Kim BS, Kim GH, Kim JJ (2012) The antagonistic properties of Trichoderma spp. inhabiting woods for potential biological control of wood-damaging fungi. Holzforschung 66: 883-887.

Li Y, Sun R, Yu J, Saravanakumar K, Chen J (2016) Antagonistic and Biocontrol Potential of Trichoderma asperellum ZJSX5003 Against the Maize Stalk Rot Pathogen Fusarium graminearum. Indian Journal of Microbiology 56: 318-327. DOI 10.1007/s12088-016-0581-9

Nagamma G, Nagaraja A (2015) Efficacy of biocontrol agents against Sclerotium rolfsii causing collar rot disease of chickpea, under in vitro conditions. International Journal Of Plant Protection 8: $222-227$

Pratt RG, Rowe DE (2002) Enhanced resistance to Sclerotium rolfsii in populations of alfalfa selected for quantitative resistance to Sclerotinia trifoliorum. Phytopathology 92: 204-209

Rifai MA (1969) A revision of the genus Trichoderma. Mycological Papers 116:1-56.
Samieto GB, Campbell CL, Lucas LT (2010) Introduction to plant disease: identification and management, New York, Van Nostrand Reinhold. 2: 267.

Samuel GJ, Ellis SD, Bolehm MJ, Coplin D (2002) CMI descriptions of pathogenic fungi and bacteria and direct sequencing of fungal ribosomal RNA. Mycological Research 100: 627-630.

Schwarze FWMR, Jauss F, Spencer C, Hallam C, Schubert M (2012) Evaluation of an antagonistic Trichoderma strain for reducing the rate of wood decomposition by the white rot fungus Phellinus noxius. Biological Control 6: 160-168

Shafique HA, Sultana V, Haque SE, Athar M (2016) Management of soil-borne diseases of organic vegetables. Journal of Plant Protection Research 56: 221 - 231

Shaigan S, Seraji A, Moghaddam SAM (2008) Identification and investigation on antagonistic effect of Trichoderma spp. on tea seedlings white foot and root rot (Sclerotium rolfsi Sacc) in vitro condition. Pakistan Journal of Biological Sciences 11: 3246-2350. DOI: $10.3923 /$ pjbs.2008.2346.2350.

Sivasithamparam K, Ghisalberti EL (1998) Secondary metabolism in Trichoderma and Gliocladium. Basic Biology, Taxonomy and Genetics. London: Taylor and Francis Ltd. 1: 139-191.

Skidmore AM, Dickinson CH (1976) Colony interaction and hypheal interference between Septoriano dorum and phylloplane fungi. Transactions of the British Mycological Society 66: 57-64.

Sundar AR, Das ND, Ishnaveni D (1995) In-vitro antagonism of Trichoderma spp. against fungal pathogens. Indian Journal of Plant Protection 23: 152-155.

Tamura K, Peterson D, Peterson N, Stecher G, Nei M, Kumar S (2011) MEGA 5: molecular evolutionary genetics analysis using maximum likelihood, evolutionary distance, and maximum parsimony methods. Molecular Biology and Evolution 10: 27312739. doi: $10.1093 / \mathrm{molbev} / \mathrm{msr} 121$.

Zeilinger S, Omann M (2007) Trichoderma biocontrol; signal tranduction pathways involved in host sensing and mycoparasitism. Gene Regulation and System Biology 1: 227-234 